\title{
BENJAMIN GRAHAM ON BUFFER STOCKS
}

\author{
BY JOHN E WOODS *
}

\begin{abstract}
Surprisingly, Benjamin Graham, the acknowledged "Father of Value Investing", considered his most important work to be the invention of the Commodity Reserve Currency Plan during the 1930s and 1940s. Previous studies of the Plan have overlooked the fact that, of its three main components (buffer stocks, price stability and currency-backing), Graham regarded the first as the most important and the other two as "secondary" or "subsidiary". By focusing on the buffer-stock aspect, we demonstrate, first, the breadth and depth of Graham's overall conception in terms of both micro-and macro-economics and, second, the considerable overlap with Keynes's ideas developed around the same time, which are manifested particularly in their common conclusion that the inefficiency of commodity markets could be rectified only by government intervention. We also comment on Mehrling's assessment of Graham as "not any kind of economist at all" (JHET, 2011).

* Independent Researcher. Contact: john.woods@cantab.net
\end{abstract}

This "preprint" is the peer-reviewed and accepted typescript of an article that is forthcoming in revised form, after minor editorial changes, in the Journal of the History of Economic Thought (ISSN: 1053-8372), issue TBA. Copyright to the journal's articles is held by the History of Economics Society (HES), whose exclusive licensee and publisher for the journal is Cambridge University Press.

(https://www.cambridge.org/core/journals/journal-of-the-history-ofeconomic-thought) This preprint may be used only for private research and study and is not to be distributed further.

The preprint may be cited as follows:

Woods, John E. Benjamin Graham on Buffer Stocks. Journal of the History of Economic Thought (forthcoming). Preprint at SocArXiv, osf.io/preprints/socarxiv 


\section{BENJAMIN GRAHAM ON BUFFER STOCKS}

\section{JOHN E WOODS}

\section{INTRODUCTION}

Benjamin Graham is best known among financial economists as a teacher and practitioner of portfolio management at Columbia University and the GrahamNewman Corporation respectively. His books - Security Analysis, written with David Dodd as amanuensis and aimed at professional analysts, and The Intelligent Investor, aimed at the layperson — have stood the test of time, as evidenced by not only the respective number of editions (six and four) but also the enduring nature of their contents applicable in different market conditions. ${ }^{1}$ For example, Graham emphasised the distinction between "investment" and "speculation" (1934, p. 54; 1973, p. 1), gave us the parable of that "very obliging partner, Mr Market" (1973, p. 108) and regarded the "Margin of Safety as the Central Concept of Investment" (1973, p. 277). ${ }^{2}$ Warren Buffett has the highest opinion of both books (2009, p. xi), having previously described the later one as "by far the best book about investing ever written" (1973a, p. vii) and graduates of Graham's university classes and investment firm as "The Superinvestors of Graham-and-Doddsville" (1973b). So, it is no surprise to learn that Security Analysis has been "regarded by many as the bible of value investing" (Klarman, 1991, p. xiv) and Graham himself was accorded the accolade, "The Father of Value Investing”.

However, it would probably come as a surprise to most financial economists, indeed most economists, to learn that Graham made an important contribution in the field of economic policy: specifically in national and international monetary arrangements, with his proposals for a Reserve Currency based on buffer stocks of primary commodities, a field not usually associated with portfolio management. What would be even more surprising is that

\footnotetext{
1 "Perhaps the most exceptional achievement of Security Analysis ... is that its lessons are timeless" (Klarman, 2009, p. xvi).

2 The "Margin of Safety" is the difference between the assessed Intrinsic Value of a security and its market price, divided by its market price.
} 
Graham regarded this as his most important work. "If my name has any chance of being remembered by future generations ... it will be as inventor of the Commodity Reserve Currency Plan” (1996, p. 293). Graham was involved in this project for just over a decade from the early-1930s, initially with a domestic focus. His first contribution appeared in 1933, followed by Storage and Stability (1937). With his second book (1944a), he extended the field of application to the global economy with the aim of having his Proposals for an International Commodity-Reserve Currency (1944b) considered at the 1944 Bretton Woods Conference, unsuccessfully as it transpired. ${ }^{3}$

In his Memoirs, Graham says that the idea for a commodity-based reserve currency occurred to him in the Depression of 1921-2, "when the world had perhaps its first real exposure to poverty in the midst of plenty". He saw things from both the supply and demand sides. On the one hand, excess raw material supplies were accompanied by disastrous price falls, "which in turn led to increasing unemployment and the vicious cycle of economic depression" ( $p$. 294); on the other hand, he was influenced around that time by John A. Hobson's The Economics of Unemployment, which emphasised the role of effective demand a decade or so before John Maynard Keynes in The General Theory: "The chief cause of depressions in the modern world ... was the public's lack of purchasing power to absorb the increased production resulting from the preceding economic booms" (p. 297). As gold producers were exempt from the difficulties facing the primary sector, Graham wondered why a basket of commodities, consisting of "the ordinary necessities of life as important and as valuable as gold" (p. 295), could not be accorded the same status as the metal in backing domestic currency. However, "I put the plan aside during the ensuing boom years: I was too busy making money on Wall Street” (p. 298).

\footnotetext{
${ }^{3}$ According to Benn Steil, both Keynes and H. Dexter White, the leader of the American delegation, excluded Graham's proposals from the agenda: Keynes because "he wanted a fiat supranational currency, Bancor, that was purchasable with, but not convertible into, gold"; White because he "simply wanted the dollar as the international currency, backed by a promise to redeem it at
} \$35/ounce”. (Private communication, 16 February 2021) 
If Graham's interest in international monetary policy is surprising to those economists at least familiar with his name, this is certainly not so with regard to Keynes, given his leading role, albeit subordinate to White, in establishing the post-war global economic arrangements at Bretton Woods. ${ }^{4}$ However, what might still be surprising to most economists is not only that Keynes's ideas for the post-war international order involved buffer stocks of raw materials, which incidentally were similar to Graham's, but also that Keynes had a long-standing interest in commodities, whether as portfolio manager on his own account and for King's College, applied economist/commentator or Government Adviser. ${ }^{5}$ There was much common ground between Graham and Keynes on the use of buffer stocks as part of their respective proposals on new international monetary arrangements but, as even the latter's ideas did not figure in policy discussions in the immediate post-war decades, what level of recognition could be expected of Graham's? Nearly two decades passed before Kaldor demonstrated the relevance of Graham's overall conception in "The Case for an International Commodity Reserve Currency":6

"The world may ultimately find that the best solution to the problem [of inadequate currency reserves is] not along the lines of a further extension of the key-currency system, nor in the creation of a world paper currency backed by the obligation of member countries, nor in the

\footnotetext{
${ }^{4}$ See Steil (2013) and Moggridge (1992, Chapters 26 and 28).

${ }^{5}$ On these aspects, see the following, where we denote The Collected Writings Volume XII by $C W X I I$ and similarly for other Volumes in that Series. First, as portfolio manager: $C W X I I$, Chapters 1 and 3; and Fantacci et al. (2010).
}

Second, as applied economist/commentator: Keynes $(1926,1938,1943)$ and $C W$ VI. Third, as Government Adviser: $C W X X V, C W X X V I I$ and Fantacci (2017). For discussion of Keynes's views on the post-war international monetary order and buffer stocks, see Ussher $(2009,2016)$ and Ussher et al. (2018) and references therein.

${ }^{6}$ Described as "in collaboration with A. G. Hart and J. Tinbergen" (1964b, p. 131, fn. 1), it was in fact written by Kaldor. See, also Hart (1991, p. 562). 
revaluation of gold, but in the monetisation of real assets other than gold" (1964b, p. 142). ${ }^{7}$

This led him to conclude that "The above line of reasoning inevitably leads to Benjamin Graham's old idea of an international commodity-reserve currency". Contrasting his approach with Graham's, Kaldor observed that he had been searching for "a universal reserve medium" that would be stable in "real value", whereas Graham had reached the same conclusion by searching for one that would stabilise "money value ... The basic considerations may not be the same, but the two approaches are obviously consistent with one another" (1964b, p. 144 , emphases in original). ${ }^{8}$

Despite Kaldor's continued advocacy, ${ }^{9}$ the idea of creating buffer stocks to stabilise commodity prices and/or to provide the basis of international monetary reform foundered. ${ }^{10}$ Following the 2007-9 Financial Crisis, the Governor of the People's Bank of China called for reform of the international monetary system, referring to Keynes's war-time proposal that was

${ }^{7}$ The other essential dimension of the "problem" related to the evolution of the key-currency system, in which the USA dollar replaced gold as both means of payment and reserve asset. This system suffered from an inherent contradiction, the "Triffin dilemma" - see Kaldor (1964a, p. 31).

${ }^{8}$ Kaldor's reference to "stable real value" brings to mind Ricardo's idea of an "invariable standard of value", discussed in The Essay on Profits (Ricardo, 1951b, pp. 1-42) and Chapter I of Ricardo (1951a). This Ricardian idea was taken up by Sraffa (1960) with his concept of "The Standard Commodity" (1960, pp. 18-25), constructed from what he called "basic commodities", a concept that will figure prominently below.

${ }^{9}$ See various essays collected in Kaldor (1978a-b, 1989) and Targetti \& Thirlwall (1989); also, Targetti (1992, pp. 308-13) and Thirlwall (1987, pp. 274-80). In his 1984 Raffaele Mattioli Lectures (1996, p. 108) and 1983 article, Kaldor still supported the idea of an international buffer-stock scheme but abandoned Graham's approach in favour of Keynes's on the grounds of practicability.

${ }^{10}$ Keynes and Kaldor are barely mentioned in Newbery and Stiglitz (1981) and Williams and Wright (1991), and Graham is not mentioned at all. 
"unfortunately not accepted" (Zhou, 2009). Also, based on the ideas of Keynes, Kaldor and Graham, Ussher and colleagues $(2009,2016,2018)$ argued that a Commodity Reserve Currency based on buffer stocks was relevant in current circumstances. As their focus was on international monetary policy, the purely buffer-stock aspects of Graham's thinking in particular have been ignored, which may have led to the conclusion that they were relatively unimportant.

However, that was not the view of Graham himself. Taking the Chinese phrase, The Ever-Normal Granary, as the central theme of his first book, Graham stated unequivocally that "The storage mechanism [is] intended primarily to cope with glut and shortage". That did not mean that it was correspondingly one-dimensional for it "is vested with the allied function of reasonably stabilizing price levels" (1937, p. vii, emphases added). Furthermore, "in the monetary field, storage of basic commodities suggests itself as the most suitable backing for a sound and adequate currency" for two reasons: first, "The unique prestige of the gold standard has been deeply undermined", creating the need for an alternative; and second, "A currency backed by, and actually redeemable in, stored basic commodities would possess an intrinsic soundness superior to that of gold" (1937, p. vi, emphasis added). Whereas the use of buffer stocks almost implies price stabilisation as a natural corollary, the potential currency-related implications require special insights, such as those perceived by Graham, Keynes and Kaldor, and recognised by Ussher and colleagues.

As shown below, Graham recognised other potential corollaries: for example, the "storage mechanism" would contribute to "general business stability" and, hence, would be an "essential preliminary step to an ever higher standard of living". ${ }^{11}$ However, as he emphasised in Chapter V, it was the physical dimension that was absolutely central: "the primary object of the proposal is to deal intelligently and constructively with the problem of surplus. Hence the storage aspect constitutes the heart of our plan". The buffer-stock

${ }^{11}$ So, a "Commodity-reserve currency can bring the world's financial economy closer to its merchandise economy and prevent world finance from interfering with the true business of the world which is to produce, exchange, and consume useful goods and services" (1944a, p. 84). 
scheme "will result in stabilising the general price level for basic commodities and will supply a sound form of currency secured by these necessary commodities [but these facts are] of secondary and collateral importance" (1937, p. 67, emphases added). Indeed, Graham argued that it could be implemented by itself without either the price-stabilisation or currency-backing features. It is for these reasons, as well as the fact that Graham had a number of insights subsequently ignored by the economics profession, that we focus in this article on the buffer-stock aspects of his proposals for a commodity reserve currency. ${ }^{12}$

A decade ago, Perry Mehrling published a critique of Graham's Monetary Economics. While not necessarily dis-agreeing with the essence of Mehrling's argument, in Section II we qualify his conclusions on Graham as an economist. Then, in Section III, we address our main theme - Graham's ideas on buffer stocks. It transpires that some of his ideas were "Keynesian" in the post-General Theory sense, although there was minimal formal contact between the two of them. ${ }^{13}$ So, we may reasonably conjecture that Graham and Keynes independently developed similar ideas on the role of buffer stocks in much the same way as they did on portfolio management. ${ }^{14}$ Section IV contains our concluding remarks.

\section{MEHRLING ON GRAHAM}

Mehrling's aim was to place Graham's “amateur proposal for a commodity reserve currency ... in the context of [his] own time and the intellectual resources available to him" (2011, p. 285, emphasis added). He observed,

\footnotetext{
${ }^{12}$ One policy instrument, Graham's Storage mechanism, seems to address three policy targets - glut and shortage, price stabilisation, currency backing. Is this a counter-example to Tinbergen's Rule (1952) more than a decade before it was initially proposed?

${ }^{13}$ The only evidence in the Keynes Archive at King's College is an exchange of letters at the end of 1943, reproduced in $C W X X V I$ (pp. 36-8). Keynes's sole reference to Graham's work is to his estimate of the cost of commodity storage in Storage and Stability (1938, p. 456, fn.; CW XVII, p. 132, fn.).

${ }^{14}$ See Woods (2013, p. 439).
} 
somewhat dismissively, that Graham "was, of course, not a monetary economist, nor indeed any kind of economist at all' (p. 286, emphasis added). In terms of academic qualifications, Graham would have agreed, perhaps because he would not then have considered himself bound by the subject's conventions: "My formal study of economics was confined to four weeks under Dr Muzzet at Columbia College in 1912. I quit the course, along with all my others that fall, to take on my daytime job for the U. S. Express Company. When I returned the next February, I could not fit economics into my schedule, and I gave it up with scarcely a second thought" (1996, p. 293). Incidentally, as Keynes read mathematics at Cambridge, neither he nor Graham had a degree in economics, although his formal study under Marshall lasted more than four weeks "Keynes had ... only about eight weeks professional training in the subject" (O’Donnell, 1989, p. 16). ${ }^{15}$

If Graham was not "any kind of economist", what was he? According to Mehrling, "He was instead a kind of investment manager" (2011, p. 286, emphasis added) - a different description follows from our opening paragraph. He describes Graham as "at root, a bond man" (p. 294), subsequently referring to him as "the bond man" (p. 297). A rhetorical device to bolster a proposed dichotomy, it is obviously inaccurate, given the content of Graham's pre-1937 writings such as Security Analysis and the articles from 1917 to 1927 collected in Klein (2009). Of the seven Parts to the former, two are devoted to Bonds (pp. 64-298, 21 Chapters in all) and two to Equities (pp. 299-473, 15 Chapters in all). As Graham made abundantly clear, the Margin of Safety is the dominant concept in both Equity and Bond analysis: indeed, the purpose of Graham and Dodd (1934) is to provide the analyst with the necessary tools to make that evaluation. ${ }^{16}$

As a Margin of Safety is the criterion for distinguishing between "investment" and "speculation", we agree with Mehrling's assertion that "The

\footnotetext{
${ }^{15}$ See also Moggridge (1992, pp. 95-7).

${ }^{16}$ In "Renaissance of Value" (Lowe 1999, p. 67), Graham acknowledged that "The value approach has always been more dependable when applied to senior issues than to common stocks", but even this would not support Mehrling's assertion about "the bond man".
} 
evil of speculation is perhaps the central theme of Graham and Dodd's Security Analysis" (p. 287. The 1934 book is undoubtedly microeconomic in nature, dealing with the analysis of individual securities. The nearest it comes to macroeconomics is in the final Chapter, discussing "Market Analysis" "business conditions; money rates; the political outlook, etc" (p. 608) — which Graham compares with "Security Analysis", the subject of the preceding 51 Chapters. The latter was more likely to be successful than the former because it was based on the Margin of Safety: "In market analysis there are no margins of safety; you are either right or wrong, and if you are wrong, you lose money" (Graham and Dodd, 1934, p. 613). ${ }^{17}$ Security Analysis is obviously directed to the individual but whether it constitutes an explicit policy proposal is a moot point — no requirements are placed on individuals, who are merely being given suggestions on security selection. By contrast, both of Graham's books contain explicit proposals on monetary policy in the form of a commodity reserve currency based on buffer stocks and, hence, have a macroeconomic dimension: but are they entirely macroeconomic? As they rely on the operation of individual markets, there is also a microeconomic dimension. In advancing a neat dichotomy and a related one-to-one correspondence — "Security Analysis is Graham's microeconomic policy proposal and Storage and Stability is his macroeconomic policy proposal" (p. 287) - Mehrling is overegging the pudding, so to speak, with the aim of drawing distinctions that are more hard and fast than they can conceivably be. So, while accepting that Graham was against speculation, it is difficult to agree completely with Mehrling that "Graham's idea of a commodity reserve currency ... must be understood as his attempt to tame the evils of speculation at a society-wide level" (p. 287, emphases added). Graham's storage mechanism should reduce the impact of speculation in commodities by narrowing the observed price ranges but whether it would have a comparable effect in securities markets is a moot point: speculation in assets can also have very serious macroeconomic consequences, as experienced globally in 2000-2 and 2007-9, to say nothing of The Great Crash.

\footnotetext{
${ }^{17}$ Keynes subscribed to this maxim: for his three "principles of successful investment", see $C W X I I$ (p. 107).
} 
However, this does not detract from the main thrust of Mehrling's article in his forensic analysis of Graham's concept of money:

“In the conflict between 'hard money' and 'soft money', we are definitely on the side of hard money. In the conflict between a 'managed currency' and an automatic currency, we are definitely on the side of an automatic, self-generating and self-liquidating currency, free of management and political pressure" (Graham, 1937, p. 146).

By his own admission, Graham was looking for a supplement to and/or replacement for gold: as Mehrling reminds us, such a conception was attractive to Hayek (1943), among others.

\section{GRAHAM'S NON-MONETARY THEMES}

In just over a decade, Graham produced three works of increasing generality on a commodity-reserve currency based on buffer stocks. The first, "Stabilized Reflation" (1933), was in Economic Forum, a journal published by the New School for Social Research, New York, which ran to only a few volumes that decade. Focussing on the USA's agricultural and raw material-producing sectors, it gave a concise account of his proposal for a domestic commodityreserve currency. That short article provided the germ of ideas for subsequent contributions - Storage and Stability, which likewise had a domestic focus, and, World Commodities and World Currency, which extended the field of application to the global economy. These books enabled Graham to provide both background on Commodity-Reserve Currency plans and detailed discussion of technical matters and the modus operandi of his proposal, neither of which was trivial. $^{18}$

Graham employed a similar conceptual framework in all three publications, demonstrating a unity of thought applied in a progressively wider context. This is manifested in what he called the "commodity unit", a basket of commodities "made up of wheat, sugar, cotton, petroleum, copper, rubber and other eligible raw materials, at least twenty-five in all” (1933, p. 187) that would

\footnotetext{
${ }^{18}$ As our focus is on underlying conceptions related to buffer stocks, we largely ignore these technical questions, recognising that neither Graham nor subsequent commentators did.
} 
have fixed monetary value. Immediately, we recognise an essential characteristic of Graham's thinking: his focus was on general overproduction of commodities rather than overproduction of individual commodities. Under Graham's plan, “The general level of commodity prices will be advanced and stabilized, and the present surplus of basic raw materials will be transformed from a cause of national disaster into a source of national strength" (p. 186, emphasis added). It would raise the price level, "taking basic commodities off the market and placing purchasing power directly in the hands of the producers" (p.190). Though the price of the commodity unit would be stabilized, "Under this measure the price of single commodities is in no wise fixed" (p. 191). The price mechanism would operate as normal for any commodity, with excess production causing its price to fall, while "the price of the twenty-four others will advance slightly to maintain the aggregate value unchanged " (p. 133, emphasis in original). So, "this Plan differs widely from valorization schemes intended to maintain the price of individual over-produced commodities" ( $p$. 191), a number of which he subsequently discussed in Chapters II and XVIII of Storage and Stability. Furthermore, Graham argued that "as far as general overproduction is concerned, our measure proposes to make it in actuality what it has always been in theory - an economic impossibility" (p. 192, emphasis in original).

In these extracts from the 1933 article, Graham was already thinking in terms not solely of microeconomics and macroeconomics as currently understood but of that old-fashioned term "political economy" which, transcending the conventional micro-macro dichotomy, refers to the economic aspects of government. With this initial insight, a careful reading of his books reveals the wide-ranging nature of Graham's conception, the extent of which has not generally been recognised even by those familiar with his work. By having something to say about economic concepts in general, the operation of markets and the State's responsibilities, Graham was taking a broader view. So, we disagree with Mehrling that Graham was not "any kind of economist at all": rather, he was a "political economist".

Such a claim can be substantiated by scale of Graham's conception as manifested in the range of themes explored, which can be organised into three groups - economic concepts and the commodity unit; microeconomics and the 
operation of markets; the State's responsibilities and macroeconomics - all of which were illustrated in the 1933 article. Of course, this organisation of material and specification of headings is to some extent arbitrary, a comment that can also be made about the inclusion of a particular theme under one heading rather than another: indeed, some themes fall naturally under more than one heading. ${ }^{19}$ In our account, we refer where relevant to Keynes, given his longstanding interest in commodity-related issues and his ideas for post-war international monetary reform: ${ }^{20}$ such comparisons will facilitate a better assessment of Graham's contribution.

\section{Economic Concepts and the Commodity Unit}

The distinction between primary commodities and manufactured goods was fundamental to Graham. "[R]aw materials are more important in the sense that they are basic and anterior, as it were, to manufactures" (1937, p. 20, first emphasis in original, second emphasis added), emphasising the point in his second book: they are "the blocks from which the economic structure is built" (1944a, p. 2). ${ }^{21}$ So, the behaviour of commodity prices was bound to influence the behaviour of manufactured goods prices but how significant was this relationship? Graham addressed this in "The Question of Price Stability" (1937, Chapter VI). After reviewing various aspects and published analysis of USA data, his conclusion was that "Price statistics show clearly that instability in rawmaterial prices is a prime cause of instability of other prices. It is the basic

${ }^{19}$ For example, we include the State's activities in buying and selling buffer stocks in the third group, recognising that they could equally have been included in the second.

${ }^{20}$ Also note from Keynes's letter to Graham of 31 December 1943: "On the use of buffer stocks as a means of stabilizing short-term commodity prices you and I are ardent crusaders on the same side" (CWXXVI, $\mathrm{p}, 38)$.

${ }^{21}$ Graham's choice of the word "basic" anticipates Sraffa's subsequent use of the same term. Sraffa defines a "basic commodity" as one which "enters (no matter whether directly or indirectly) into the production of all commodities" $(1960, \S 6$, p. 8 , emphasis in original). Kaldor $(1976,1983)$ also employs the term "basic commodities". 
commodities that decline fastest and farthest, carrying other prices down with them. They also advance soonest and farthest in boom times, and again influence other prices in the same direction" (p. 85). ${ }^{22}$

To Graham, commodities should naturally be regarded as an asset precisely because they were basic: "a plenitude of natural resources is the very fountainhead of national - and world - prosperity" (1937, p. 17). That they were not he regarded as paradoxical, citing a comparison with gold. Noting that commodity inventories had been relegated to "their present and inferior status", he concluded that "we have formed individual concepts of what constitutes wealth, and what forms of wealth are preferable to others, which have no support in concrete realities and which depend for their validity on the persistence of a fundamentally irrational mass psychology" (1937, p. 11, emphases added).

Pursuing this idea about the nature of commodities, Graham argued that "Whether a commodity reserve system will function as a national asset or a national liability depends upon the mechanism under which it operates. It is entirely a question of technique. A stockpile is beneficial ... if it is set up solely to meet future needs. When the objective is that of early sale, then a stockpile is likely to prove unsettling to the markets and expensive to those who hold it" (1944a, p. 29, emphases in original). This led him to draw "The distinction between conservation for use and conservation for sale ... In the former case, the reserve is established to meet a future need which experience has taught us is likely to develop... The sale is not the end in itself but only the means of bringing the stored surplus into use". On the other hand, after reviewing the recent history of various government policies to deal with surplus, he concluded that operations "merely to maintain the price are likely to be ill timed and unsuccessful ..., vulnerable to adverse developments" (1937, pp. 35 and 34, emphasis in original) and encourage speculation and gaming by virtue of their short-term horizon.

${ }^{22}$ In the Notes to that Chapter, he presented a summary Table, referring to Snyder (1934). Kaldor supported Graham's position, arguing that commodityprice rises would cause inflation in developed countries in three ways: a direct impact on production costs, influencing inflation expectations and wagebargaining (1989, pp. 245-6). 
There is more than a hint here of Graham's distinction between investment and speculation so that it is possible to suggest a one-to-one correspondence with the distinction relating to conservation: on the one hand, investment and future use and, on the other hand, speculation and imminent sale. $^{23}$ What Graham was doing, perhaps unwittingly, was to express an affinity with a conception of economics that emphasises production over exchange among its characteristic activities: in other words, that "value" over the long term is derived from costs of production rather than individual utility, thereby identifying himself with Classical rather than Neo-Classical economics. ${ }^{24}$

Having discussed these general questions, it is natural at this point to consider Graham's specific idea of the commodity unit, which was central to his proposals for a commodity-reserve currency, whether in a national or an international context. Whereas Keynes's Proposal was for individual buffer stocks, ${ }^{25}$ Graham's was for "The State to acquire and store composite units of basic raw materials when there is a surplus of these commodities in the aggregate" (1937, p. 49): in his earlier book, the commodity unit would consist of individual actively traded commodities, weighted in proportion to their

${ }^{23}$ If implementation of Graham's proposal reduced speculative activity, we can agree with Mehrling that it would attenuate the impact of speculation at the whole-economy level but, as noted above, asset speculation can have serious macroeconomic consequences.

${ }^{24}$ For a discussion of this "production-exchange dichotomy", see Chapter 1 of Pasinetti (2007), for example.

${ }^{25}$ See $\S$ II of Keynes (1942) but note that, in Chapter 38 of CW VI, he had discussed the role of a "tabular standard" of some 62 "standardised foods and raw materials of world-wide importance" in the context of international monetary management; subsequently, in a published exchange with Professor Frank Graham, he stated that "I have no quarrel with a tabular standard as being intrinsically more sensible than gold. My own sympathies have always fallen this way" (1944, p. 429). Against the conventional interpretation of this passage, Ussher et al. argue that "this quote does represent Keynes' long-run vision for the post-war global financial architecture and is even reflected in his original [International Clearing Union] proposals" (2018, p. 27). 
relative production or consumption in the United States. ${ }^{26}$ Given the initial value of the commodity unit, Graham's Proposal would operate in essentially the same way as Keynes's, with the commodity unit replacing the individual commodity. So, the Government would buy units (Graham referred to "warehouse receipts") when the unit price fell below the prespecified initial value, selling them when it rose above. In effect, there would be a two-stage procedure involving arbitrageurs and the Government: in the first stage, arbitrageurs would trade with the Government; and in the second stage, they would trade in the markets for the individual commodities. "In this way commodity units would be broken up and brought into the various open markets" $\left(1937\right.$, p. 60). ${ }^{27}$

Commodities included in the unit would have to satisfy certain criteria: for each, there would have to be a high degree of standardisation, reasonable durability in storage, reasonable storage costs and there would have to be dealing on a recognised exchange. Having established these criteria, the next question related to the price of the commodity unit: there would be obvious advantages if it could be chosen sufficiently higher than the prevailing figure so that commodity units could be bought at the outset. ${ }^{28}$ To illustrate his line of thinking, we can refer to the account in Storage and Stability, Chapter IV. For the commodity unit's weighting structure, he proposed the 1921-30 average production or consumption for each commodity, with the corresponding average

${ }^{26}$ In the later book, the weighting structure would be based on world output or world trade: Graham preferred the latter because it "measures a product's significance as an international commodity" (p. 73), a view shared by Kaldor (1964b, pp. 148-9).

${ }^{27}$ Graham illustrated how this process would operate, referring to what had happened after the dissolution of Standard Oil of New Jersey into 39 constituent enterprises. "A market was established for each of the individual companies. But at the same time trading continued in the 'old shares,' meaning thereby the package of securities which the holder of one old share received. These 'old shares' ... were, in effect, composite units made up of diverse amounts of 39 different securities" (1937, pp. 61-2).

${ }^{28}$ A point also made by Kaldor (1964b, pp. 158-61). 
price used to calculate the overall price level. ${ }^{29}$ Graham estimated that the resulting price level "would be about 4 per cent higher than the level prevailing in June 1937", thereby satisfying the preferred pre-condition. Determining the price level was "a matter of the highest importance, for it means stablishing the purchasing power of the dollar in terms of basic raw materials" but Graham then apparently contradicted himself, saying that "It is not necessary for us to press overstongly for the acceptance of our proposed 1921-1930 price level, since the mechanism of the Reservoir system is in no way dependent upon the particular level selected" (1937, pp. 55, 56). ${ }^{30}$

Keynes's approach to price-setting was doubtless facilitated by the fact that he was dealing with individual, rather than a basket of, commodities. The aim of international policy for Keynes should be to establish a "long-term economic price": by this, he meant not a "low" price determined by "A minority of producers with low standards of life" but one "best defined as representing the long-period equilibrium costs of the most efficient producers on the assumption that the return to the latter is sufficient to provide them with proper nutritional and other standards in the conditions in which they live" (CWXXVII, p. 123). It was in everyone's interests that the price of a commodity should not fall below that level. This "long-term economic price" would be subject to periodic review, Keynes envisaging that any price changes would be "small and gradual", with downward revisions not normally exceeding 5\% (CWXXVII, p. 118). It is evident from the 1933 article and the first Chapter of each book that Graham would have endorsed Keynes's line that the price level should support at least a decent standard of living. ${ }^{31}$

${ }^{29}$ See Table I in Graham (1937, p. 57) and the related commentary, which contain some minor arithmetical errors.

${ }^{30}$ The price level would influence the standard of living of primary producers since it would define the level at which the Reservoir system came into operation. The structure of the commodity unit should be consistent with chosen price level, reflecting conditions in the corresponding period.

31 "Most serious is the effect of price collapses on the position of those countries chiefly dependent on the production and export of raw materials. The reduction 
The obvious area of difference between Graham and Keynes was in the definition of the buffer-stock unit, with Graham favouring a basket and Keynes an individual commodity. Graham devoted a chapter to this in each book, acknowledging in the second that individual stabilization was "the most direct and simplest approach to the problem" (1944a, p. 58). In Chapter VI of Storage and Stability, he discussed what would happen if a shortage in one commodity caused a significant increase in its price: "Would not this enormous rise have to be offset by a decline in all the other commodities in the unit, thus demoralizing their markets and hurting their producers?" Answering this question in the negative, Graham advanced three lines of argument. The first was empirical: "no such completely disproportionate advance has actually occurred in any one of the components", the reason being that basic commodities were produced world-wide so that "a five- or tenfold advance in price within a short period is (barring war) a commercial impossibility" (1937, p. 69); furthermore, the less important a commodity in the unit, the lower would be the impact of its price increase on the other commodities". ${ }^{32}$ The second argument was that his Proposal permitted "the replacement of 'spot' commodities by futures". The normal relationship was for futures to be at a premium over spot. So, "when there is a shortage ... of some kind [and] this normal relationship is reversed" (1937, p. 70), it was always possible to sell the physical or spot and replace it by futures contracts. The third argument was that there was always "a sovereignly effective method of dealing with [any great disturbance from an unruly advance in some individual commodity], viz., the temporary suspension of the offending commodity from the unit" (1937, pp. 71-2).

A contrary line of argument based on elasticities in "ordinary supply and demand analysis" was advanced by Calsoyas (1948) and Tyszynski (1950). ${ }^{33}$ To illustrate, if the commodity unit consisted of foodstuffs and industrial raw materials, "the support of the raw material prices during a trade depression will

of the national income and the impairment of the living standards of the population are catastrophic" (1944a, p. 7).

32 The supporting evidence is contained in Table III of Appendix I (1937, p.

271): see also Note 4 to Chapter V (1937, pp. 246-7).

${ }^{33}$ As pointed out by a referee. 
give rise to undesirable 'windfall' gains to farmers, while an attempt to moderate steep rises of raw materials during a boom will equally make farmers suffer 'windfall' and substantial losses" (Tyszynski, 1950, p. 441). If not disputing the theoretical argument in a partial equilibrium context, Graham would most likely have appealed to the empirical evidence to dispute the point about "steep" rises and falls. ${ }^{34}$ It would also have been necessary to consider the income effects and how the windfalls were spent.

In his later book, Graham examined this question of composite versus individual stabilisation from a different - macroeconomic - perspective. As we discuss the macroeconomic dimension of Graham's Proposals under our third heading in this Section, we defer further consideration.

\section{Microeconomics and the Operation of Markets}

From the outset, Graham recognised the problems facing agricultural and primary commodity-producing sectors. In the domestic context, he perceived "the chronic and central weakness of agriculture" as due to an "Inability to sell at a fair price [and an] inability to hold output in suitable relationship to effective demand" (1937, p. 14). There were obvious underlying technological reasons as producers were unable to restrict output quickly: "the manufacturer can adjust his production to demand much more readily than the farmer" $(1937$, p. 20$)$. The outcome was that, compared with manufactured goods, basic commodity prices were much more volatile. In a wider context, Graham regarded "The instability of raw-materials prices due ... to cyclical unbalances between production and consumption" as of "the first importance" (1944a, p. 3).

In his 1926 article, Keynes noted a characteristic of many staplecommodity markets that a relatively small excess production, say $10 \%$, could cause a disproportionate price fall $(C W X I X, \mathrm{p} .548)$. He took this a stage further

\footnotetext{
${ }^{34}$ For example, if buffer stocks were bought (respectively, sold) when the composite price was, say, $5 \%$ or $10 \%$ lower (respectively, higher) than the preset level. Graham also recognized the problem with individual commodity stabilization if the price set by the State was lower than the "long-run economic price" (1937, pp. 41-2).
} 
in the 1938 article, identifying four commodities - rubber, cotton, wheat and lead as representative of those produced and marketed under competitive conditions - where price fluctuations were "quite staggering". His chosen metric, the percentage by which the highest price exceeded the lowest in a given year, indicated intra-year variability. He found that the average over the period 1928-1937 was $96 \%$ for rubber, $42 \%$ for cotton, $70 \%$ for wheat and $61 \%$ for lead. Even a cursory examination of individual commodity and Index price data in the IMF Primary Commodity Database demonstrates that the particular feature identified by Keynes is an enduring one in the $21^{\text {st }}$ century. ${ }^{35}$

This data also illustrates the other side of the price volatility coin income instability. "Most serious is the effect of price collapses on the position of those countries chiefly dependent on the production and export of raw materials" (1944a, p. 7). ${ }^{36}$ Graham referred, in particular, to the "catastrophic" reduction in national income and impairment of the living standards of the population.

In principle, imbalance between supply of and demand for a storable commodity could be met, at least partially, by inventories. This was a topic on which both Graham and Keynes had similar views, educated no doubt by personal experience. To Graham, "The modern world is not geared properly to the storage of goods" even though, on the one hand, storage techniques had been considerably improved and, on the other, "our very productivity has created a greater need than ever before for the use of commodity [inventories]" (1944a, p. 23). Furthermore, "modern business technique strongly favours holding down such inventories to the lowest practicable figure" (1944a, p. 24). Keynes echoed Graham's assessment: “The competitive system abhors the existence of stocks,

${ }^{35}$ It also demonstrates that there is sufficient variability of commodity Indices to make the modus operandi of Graham's Proposal feasible.

${ }^{36}$ See United Nations Conference on Trade and Development (2019). One example of dependence is Madagascar, which supplies $80 \%$ of the world's natural vanilla: the Financial Times (2018) reported that, between 2015 and 2018 , the price rose from less than $\$ 100 / \mathrm{kg}$ to around $\$ 520 / \mathrm{kg}$, having peaked at over $\$ 600 / \mathrm{kg}$. On the other hand, prices fell from $\$ 300-400 / \mathrm{kg}$ in 2003 to around $\$ 30 / \mathrm{kg}$ in 2004 . 
with as strong a reflex as nature abhors a vacuum" (1938, p. 449). So, raising this elementary microeconomic question leads naturally to an examination of how commodity markets operated.

Graham observed that "The carrying of stocks of merchandise to meet any special demand has been made more and more the function and burden of the producer. But the manufacturer, in turn, has accepted this burden with the utmost unwillingness" (1937, p. 12). If producers would not accept the burden of inventories, then surely speculators would, according to accepted theory. However, Graham argued that speculation did not perform its expected role. Indeed, "if the wrong buttons are pressed, the storage or inventory machinery may operate in the contrary direction" $(1937$, p. 14). Noting that the price mechanism was the theoretical basis for the inventory-adjustment process and calling on his experience in asset management, Graham observed that the law of supply and demand did not operate automatically and impersonally but through the sound common sense of businessmen. "When this sound common sense is supplanted by speculative enthusiasm on the one hand or by fear or financial necessity on the other, we have exactly the opposite sequence of events - a phenomenon with which we are only too familiar in the stock market, where advancing prices tend to attract buying and declining prices to induce selling". So, participants, even speculators, would be adopting positive-feedback rather than negative-feedback strategies. Though economists regarded such contradictions of the law of supply and demand as temporary aberrations, "the almost pathological fear for increasing inventories ... interposes a really formidable obstacle to the normal functioning of the inventory mechanism as a stabilizing factor in upswings and downswings of the business cycle... [Indeed,] In serious depression, we find the urge to liquidate is cumulative rather than self-correcting" (1937, p. 15).

Keynes (1938) agreed with Graham. It could not be assumed, as in conventional theory, that speculators would act quickly in a falling market to correct disequilibrium because they might prefer to hold back, anticipating an even larger subsequent gain. As their long-term holding power was limited and most were interested in rapid turnover, speculators would be induced to enter the 
market only after a drastic fall in price below normal production cost. ${ }^{37}$ In other words, speculation did not necessarily work as a natural equilibrating force and so markets were not efficient. Keynes concluded that "Assuredly nothing can be more inefficient than the present system by which the price is always too high or too low and there are frequent meaningless fluctuations in the plant and labour force employed" (1938, pp. 451-2).

These were not merely theoretical arguments as both Graham and Keynes had considerable experience of how markets actually operated. Graham's was of securities markets which, by dint of the techniques he developed there, would have provided insights into the workings of commodities markets. Keynes was very actively involved in both securities and commodities markets, the latter especially in the 1920 s and $1930 \mathrm{~s},{ }^{38}$ and we should not forget his detailed knowledge manifested in the series of Special Memoranda, "Stocks of Staple Commodities", published annually between 1923 and 1930 (CW XII, Chapter 3). So, the critiques provided by Graham and Keynes can be regarded as authoritative.

The price mechanism did not operate satisfactorily in commodity markets because merchants and speculators, the "middlemen", were not responding to price signals in the expected way. Kaldor (1983) advanced the argument that such agents would adopt negative-feedback strategies only if they had a firm expectation of the normal or long-run price of each commodity, deviations from which would be temporary. However, short-term commodity-price variability, as illustrated by Keynes, has continued to be very large. This is an instance where volatility can be taken as an indicator of risk. Kaldor concluded that "any variation in the carry-over of stocks from period to period will be associated with an even greater variation of prices, which in turn will have further repercussions on the traders' willingness to take risks. Thus unregulated commodity markets, contrary to the generally held belief, represent a highly

${ }^{37}$ So, Graham and Keynes were arguing that there were Limits of Arbitrage (Shleifer and Vishny, 1997).

${ }^{38}$ See, for example, Tables 3 and 4 in $C W X I I$ (pp. 11 and 12). For accounts of Keynes's activities in commodity markets, see Fantacci et al. (2010) and Marcuzzo and Sanfilippo (2016). 
wasteful and primitive instrument for aligning the supply and demand for commodities" (1989 [1983], p. 240, emphasis added).

For Graham, regulation would be through the use of buffer stocks, based on his composite commodity: then, the price mechanism could play its proper role in dealing with commodities as a whole. He was "convinced that a substantial degree of flexibility in individual prices is a prime necessity in a free and soundly functioning economic system" (1944a, p. 51). For "Price is the factor that is relied upon to make the inventory mechanism function in the right direction. The low prices that accompany excess production are an inducement to build up inventories, and the converse is true when output fails or demand increases sharply" (1937, pp. 14-5). There would be individual commodity price flexibility within the framework of an overall fixed price level for the composite unit so that "the relative prices of the individual products would be free to fluctuate in accordance with economic developments" (1937, p. 42). As shown under the next heading, Graham argued that, through its transactions in commodity units, the State would perform the macroeconomic stabilising role that would have been performed collectively at the microeconomic level by merchants and speculators. So, he concluded that his Proposal, which offered individual price flexibility within composite-unit price stability, "is a desirable synthesis of the two objectives. Stability is most needed for the whole; flexibility is most necessary for the parts" (1944a, p. 61). There was an important corollary, "Flexibility in individual prices has the great additional advantage of permitting long-term price changes to be made without interference" (p. 62, emphasis in original). In other words, what would happen as a periodic adjustment to an individual commodity price by the corresponding buffer-stock manager under Keynes's arrangements would be determined by the market under Graham's. For this reason, Graham concluded that "There are no inherent disadvantages of consequence in aiming at a fixed value for a composite of commodities" (1944a, p. 61).

\section{The State's Responsibilities and Macroeconomics}

As just noted, Graham and Keynes had concluded that producers and merchants/speculators could not correct commodity market imbalances: so, who could assume the responsibility? They agreed that only the Government in a 
domestic context or a supra-national body in an international one could perform that role. As Graham put it in Storage and Stability, "Surplus has become a challenge to the State", which could be addressed in any of four ways: "(a) by preventing it; (b) by destroying it; (c) by 'dumping' it; or (d) by conserving it" (p. 18). He preferred (d) if a technique could be designed so that inventories would be used solely to meet future needs. Only those basic commodities satisfying the necessary criteria, such as standardisation and durability, would be included: the notion of a Basic Commodity is crucial, focussing on the importance of a commodity to the economy as a whole. Such commodities would, therefore, always be required, which meant that "A rational plan for conserving surplus, which recognizes the relative importance of the products to which it applies, should not involve the State in financial difficulties". Rationality is multi-dimensional, incorporating purpose (for future use rather than immediate sale), object of application (basic commodities that are standardised and durable) and pricing (broadly in line with, if not slightly above, the long-run economic price). Such is the power of this notion that it implies the following Fundamental Principle underlying Graham's Proposals: “The State can always afford to finance what its citizens can soundly produce" (1937, p. 43, emphasis in original). As a corollary, he could then conclude that a sensible buffer-stock arrangement would be in the national interest. Conceptually, it was straightforward to extend this line of argument to a global context in World Commodities and World Currency.

This is an appropriate point to discuss briefly the Government's (or an international body's) trading activity. Initially, Graham examined whether acquiring surplus output at an abnormally low cost could be successfully followed. Acknowledging that the concept of a low price was necessarily indefinite, he argued that "a policy based on some arbitrary but conservative formula, such as buying whenever the price fell to 50 per cent of the 10-year average and selling, say, at 25 per cent above this average, the net financial result of these operations could scarcely help but be favourable". ${ }^{39}$ He concluded that

\footnotetext{
${ }^{39}$ Graham modified his account as follows: "Commodity units shall be acquired whenever obtainable at a small discount below their established value... If the
} 
"Such an arrangement would amount simply to putting the State in the role of $a$ shrewd long-term operator in basic commodities, blessed with an unlimited bank roll' (1937, p. 39, emphasis added). That is, the State would be acting as a genuine "value investor" whose decisions were taken by reference to the Margin of Safety: the State would be investing, not speculating.

In this article, we have deliberately avoided the monetary aspect of Graham's and Keynes's buffer-stock Proposals. Nonetheless, it is briefly worth considering this aspect before turning to their genuine macroeconomic dimensions. In a domestic context, we note, first, Graham's suggestion that "commodity-unit certificates, representing the physical commodity units in storage, would constitute an ideal medium of investment for our social security fund" (1937, p. 100, emphasis added). Such a fund, if managed by "a shrewd long-term operator", would be able to adopt a corresponding long-term approach and, hence, take advantage of intrinsic commodity-price volatility, while simultaneously limiting it. In an international context, the role of an individual government could be replaced by that of a supranational body such as the IMF or World Bank or even a consortium of governments. Furthermore, other genuine long-term institutions, such as sovereign wealth funds and larger public-sector pension funds, could also participate. In this way, the question of buffer stocks could be separated from that of a new reserve currency, thereby confirming Graham's initial intuition that "The primary object of the proposal is to deal intelligently and constructively with the problem of surplus. Hence the storage aspect constitutes the heart of our plan" (1933, p. 67).

Turning to macro-economics, there are three related dimensions to Graham's thinking. First, his buffer-stock proposal would contribute to attenuating the problems of the business cycle. Graham devoted a Chapter in Storage and Stability to "The Reservoir System and the General Business Cycle": "our Reservoir system takes on a new stature as an essential regulatory mechanism for the normal systole and diastole of the breath of business" (1937, p. 89). In his second book, Graham concluded that "Since [our plan] will eliminate wide fluctuations in prices it will narrow the swings of the business

composite price of the commodities advances above the established standard, [commodity units shall be sold]" (1937, p. 49). 
cycle, and thus reduce unemployment caused by cyclical depressions" (1944a, p. 119). Keynes also recognised "Commodity controls as a contributory measure to the prevention of the trade cycle" as well as diminishing "the meaningless shortperiod price swings affecting particular commodities" (CW XXVII, pp. 121-2).

A decline in effective demand in industrialised countries would affect commodity prices and, hence, primary producers' incomes, lowering effective demand there, which would then feed back onto effective demand for the products of the industrialised countries. By supporting incomes in primaryproducing countries, a buffer-stock scheme would inhibit such a "vicious cycle" at the outset. At the other end of the trade cycle, with industrialised countries' output growing rapidly, there would be upward pressure on commodity prices: sales of buffer stocks could then prevent raw-material price inflation carrying the seeds of an incipient boom. Furthermore, a buffer-stock scheme would have a more immediate impact than fiscal and/or monetary policy: "we have at our disposal a weapon capable of producing large effects by rapid action, and of operating in the negative as well as in the positive direction, so that it can function as a stabilising factor both ways" (CW XXVII, p. 121).

The second is related to balanced growth: "let us make the basic point that the stabilization we seek is ancillary and subordinate to the wider goal of balanced expansion of output" (1944a, p. 58). Balanced growth is a recurring, fundamental idea in Graham's books. Indeed, his second opens thus: "The basic problem of raw materials is how to reconcile stabilization with expansion" (1944a, p. 1). A few pages later, Graham opines that "The world has not yet learned the technique of balanced expansion without resultant commercial and financial congestion" (p. 5), subsequently arguing that, under his plan, "as production of the components [of the commodity unit] is kept in fairly sound balance there should not be any disturbing revolutions in the economic position of one against the other. Of overwhelming importance is the fact that balanced expansion in all the items collectively can proceed unabated without the familiar and disastrous consequences of price collapse" (p. 98, emphasis in original). Implicit in Keynes's writings on the trade cycle, this theme of inter-sectoral balance between commodity-producing and industrial countries has been particularly emphasised by Kaldor $(1974,1976,1983)$, who argued that "if the world were rationally organised, the only true constraint on the growth of world 
industrial production would be the availability of basic materials and food" (1978b [1974], p. 98),

The third macro-economic theme is unemployment. Having shown that the unfettered operation of competitive markets would not necessarily generate a satisfactory outcome, Graham went much further than this with his "Keynesian" declaration that "Widespread unemployment operates as a crude mechanism for correcting the unbalance of demand and supply" (1937, p. 91). This was a prelude to his conclusion that "The Reservoir system, by providing a permanent stimulus to trade and production, and by interposing an effective buffer between business stresses and depression, should supply a sturdy foundation upon which to construct a sane and flexible employment policy" (1937, p. 94). This point was re-iterated in his second book: "We do not assert that our plan to stockpile and stabilize raw materials will guarantee full employment. We do say that it will contribute greatly toward that end by expanding the output of primary commodities and increasing the purchasing power of numerous small producers" (1944a, p. 119).

\section{CONCLUDING REMARKS}

"Why has not the stockpile principle emerged as a fundamental factor in economic policy - both national and international? Why has it failed to entrench itself in the thinking of either the man in the street or the trained economist?" (Graham, 1944A, p. 24).

Seventy-five years later, Graham's questions remain unanswered. In his Economic Journal Note, responding to Professor Frank Graham's article on a Commodity Reserve Currency (1944), ${ }^{40}$ Keynes suggested that the main reason was political: "This does not strike me as an opportune moment to attack the vested interests of gold holders and gold producers... [Rather,] The right way to approach the tabular standard is to evolve a technique and to accustom men's minds to the idea through international buffer stocks" (1944, p. 430). This takes us back to Graham's original conception “to deal intelligently and constructively with the problem of surplus" (1937, p. 67), the heart of his plan being the storage

${ }^{40}$ No relation to Benjamin Graham, Frank Graham had espoused his Proposals. 
aspect. As he stated, "the plan could be operated without [either] the pricestabilisation feature ... [or] its monetary aspect” (1937, pp. 67-8): regarding price stabilisation, the price of the commodity unit need not be fixed but could "fluctuate within wide limits before commodities were acquired and liquidated" (p. 68). To Graham, the price-stabilisation and monetary aspects, while inherently advantageous, were nevertheless "subsidiary aspects [of] secondary importance" p. 67). So, as Keynes suggested, this is a way in which "the stockpile principle" could entrenched "as a fundamental factor in economic policy".

What has emerged from our discussion of Graham's proposal on buffer stocks is the considerable overlap between his conception and Keynes's, manifested particularly in their accounts of the role of speculators in commodity markets and the working of commodity markets. Both argued that these markets were, in modern parlance, inefficient, a feature that could be rectified only by government intervention. Nonetheless, both recognised the essential role of the market mechanism: Graham in the modus operandi of the commodity unit; and Keynes with his statement that "Our object should be to combine the longperiod advantages of free competition with the short-period advantages of ensuring that the necessary changes in the scale and distribution of output should take place steadily and slowly in response to the steady and slow evolution of the underlying trends" ( $C W X X V I I$, p. 126), with which Graham would have thoroughly agreed. There are sufficient differences in their approaches to prevent us from concluding that there is a Keynes-Graham schema in international monetary policy based on buffer stocks comparable to the KeynesGraham schema in portfolio management. Nevertheless, there is a natural connection between the two fields, recognised by both Graham and Keynes, when the State assumes "the role of a shrewd long-term operator in basic commodities".

The individual who tried to keep Graham's - and Keynes's - ideas on the post-war international economic policy agenda was Kaldor. A comprimario in our narrative, he intermediated between the two principal characters. Advocating Graham's Proposal of 20 years earlier in the 1964 UNCTAD submission with a Keynesian dimension, he subsequently committed to Keynes's war-time Proposal on grounds of practicability. Among his contributions, there 
are four which are particularly relevant, incorporating Grahamite and Keynesian themes. First, he emphasised the inter-sectoral aspect between the primary and the industrial, which had macro-economic implications for growth and inflation (1976, pp. 704-8). Second, he was extremely critical of the market mechanism, which he regarded as very inefficient in securing adjustments because middlemen did not perform the role assigned to them in conventional economic theory (1989 [1983], pp. 237-40). Third, buffer stocks could provide the basis for a satisfactory adjustment mechanism: "The system of buffer stocks would thus substitute the mechanism of income-stabilising variations in stock accumulation for the crude mechanism of rising and falling commodity prices which latter, as we have seen, operates slowly and wastefully, and tends to set up perverse and unnecessary cycles in world industrial activity" (1976, p. 713). ${ }^{41}$ Fourth, and integrating the first three, he argued that, under a system in which primary producers received steadily growing income in terms of international currency in line with the growth of their output, the growth of their demand for industrial goods would cause multiplier and accelerator effects. The result of this would be that the growth rate of primary production would determine the growth rate of industrial production rather than the other way round. As he put it in a Preface to Grondona: "In the longer run, it is the supply of basic materials which would set the limit to the rate of growth of world industrial production and not, as now, the rate of growth of effective demand emanating from the advanced countries, which governed the trend rate of growth of investment and production of primary commodities" (1975, pp. 16-7, emphasis added).

\footnotetext{
${ }^{41}$ Also, "The 'alignment' of the two sectors would take place ... by income variations - or rather by induced changes in the rate of growth of industrial output and incomes" (Kaldor, 1989 [1983], p. 245).
} 


\section{Acknowledgements}

I am very grateful to the referees for their detailed, constructive criticism of previous versions and to the Editor, Professor Duarte, for guidance. I am responsible for all remaining errors of fact and interpretation.

I dedicate this article to P. D. and A. M.

\section{REFERENCES}

Buffett, W. 1973a. "Preface" to Graham (1973): vii-viii.

Buffett, W. 1973b. “Appendix, The Superinvestors of Graham-and-Doddsville" to Graham (1973): 291-313.

Buffett, W. 2009. "Preface" to Graham and Dodd (2009): xi-xii.

Calsoyas, C. D. 1948. "Commodity Currency and Commodity Storage." American Economic Review, 38 (3): 341-52.

Fantacci, L. 2017. 'Reconciling Money and Goods: Keynes's Commodity and Currency Plans for the PostWar World." Annals of the Fondazione Luigi Einaudi LI: 149-76.

Fantacci, L., Marcuzzo, M. C., and Sanfilippo, E. 2010. "Speculation in Commodities: Keynes' "Practical Acquaintance" with Futures Markets." Journal of the History of Economic Thought 32 (3): 397-418.

Financial Times. 2018. “The Big Read. Commodities.” by David Pilling, 6 June.

Graham, B. 1933. “Stabilized Reflation.” Economic Forum: 186-93.

Graham, B. 1937. Storage and Stability. New York: McGraw-Hill.

Graham, B. 1941. "Summarization of the Multiple Commodity Reserve Plan". In Lowe (1999): 239-45.

Graham, B. 1944a. World Commodities and World Currency. New York: McGraw-Hill.

Graham, B. 1944b. "Proposals for an International Commodity-Reserve Currency". In Lowe (1999): 233-8.

Graham, B. 1973. The Intelligent Investor. New York: Harper \& Row.

Graham, B. 1974. “Renaissance of Value.” Barron's, 23 September 1974. Reprinted in Lowe (1999): 63-9.

Graham, B. 1996. The Memoirs of the Dean of Wall Street. New York: McGraw-Hill. 
Graham, B and Dodd, D. 1934 (First edition), 2009 (Sixth edition). Security Analysis. New York: McGraw-Hill.

Graham, F. D. 1944. "Keynes vs. Hayek on a Commodity Reserve Currency." Economic Journal 54: 422-9.

Hart, A. G. 1991. "Nicholas Kaldor as Advocate of Commodity Reserve Currency”. In E. J. Nell \& W. Semmler, eds., Nicholas Kaldor and Mainstream Economics. London: Macmillan, pp. 561-70.

Hayek, F. A. 1943. “A Commodity Reserve Currency.” Economic Journal 53, $176-84$.

Hobson, J. A. 1922. The Economics of Unemployment. London: George Allen \& Unwin.

Kaldor, N. 1964a. "The Problem of International Liquidity." Bulletin of the Oxford University Institute of Economics and Statistics 26(3). Reprinted in N. Kaldor, Essays on Economic Policy, Volume II. London: Duckworth, 1964, pp. 28-47.

Kaldor, N. 1964b. "The case for an international commodity reserve currency, in collaboration with A. G. Hart and J. Tinbergen”. In N. Kaldor, Essays on Economic Policy, Volume II. London: Duckworth, 1964, pp. 131-177.

Kaldor, N. 1974. "International Monetary reform: the Need for a New Approach.” Bancaria. Reprinted in Kaldor (1978b), pp. 90-9.

Kaldor, N. 1975. "Preface” to L. St Clare Grondona, Economic Stability is Attainable. London: Hutchinson, pp. 16-7 .

Kaldor, N. 1976. "Inflation and Recession in the World Economy." Economic Journal 86 (344): 703-14.

Kaldor, N. 1978a. Further Essays on Economic Theory. London: Duckworth.

Kaldor, N. 1978b. Further Essays on Applied Economics. London: Duckworth.

Kaldor, N. 1983. "The role of commodity prices in economic recovery." Lloyds Bank Review, July 1983. Reprinted in Kaldor (1989), pp. 235-50.

Kaldor, N. 1989. Further Essays on Economic Theory and Policy. London: Duckworth.

Kaldor, N. 1996. Causes of Growth and Stagnation in the World Economy. Cambridge: Cambridge University Press.

Keynes, J. M. 1926. "The control of raw materials by governments.” The Nation and Athenceum, 12 June 1926, reprinted in CW XIX: 546-52. 
Keynes, J. M. 1936. The General Theory of Employment, Interest and Money. London: Macmillan.

Keynes, J. M. 1938. "The policy of government storage of foodstuffs and raw materials." Economic Journal 48, 449-60.

Keynes, J. M. 1942. “The international control of raw materials.” Journal of International Economics 4, 1974. Reprinted in CW XXVII: 112-33.

Keynes, J. M. 1943. "The objective of international price stability.” Economic Journal, 53: 185-7.

Keynes, J. M. 1944. "Note by Lord Keynes.” Economic Journal 54: 429-30.

Keynes, J. M. The Collected Writings of John Maynard Keynes, D. Moggridge (ed.). Cambridge: Cambridge University Press.

Volume VI - A Treatise on Money, 2 - The Applied Theory of Money, 1971.

Volume XII - Economic Articles and Correspondence - Investment and Editorial, 1983.

Volume XIX - Activities 1922-1929: The Return to Gold and Industrial Policy, 1981.

Volume XXV - Activities 1940-1944: Shaping the Post-War World, The Clearing Union, 1980.

Volume XXVI - Activities 1941-1946: Shaping the Post-War World, Bretton Woods and Reparations, 1980.

Volume XXVII - Activities 1940-1946: Shaping the Post-War World, Employment and Commodities, 1980.

Klarman, S. A. 1991. Margin of Safety. New York: HarperBusiness.

Klarman, S. A. 2009. "Preface, The Timeless Wisdom of Graham and Dodd" in Graham and Dodd, 2009: xiii-xl.

Klein, R. G. (Ed.) 2009. Benjamin Graham on Investing. New York: McGrawHill.

Lowe, J. (Ed.) 1999. The Rediscovered Benjamin Graham. New York: John Wiley \& Sons, Inc.

Marcuzzo, M. C. and Sanfilippo, E. 2016. "Keynes and the interwar commodity option markets." Cambridge Journal of Economics 40 (1): 327-48. 
Mehrling, P. 2011. "The monetary economics of Benjamin Graham: a bridge between goods and money?" Journal of the History of Economic Thought 33 (3): $285-305$.

Moggridge, D. E. 1992. Maynard Keynes: An Economist's Biography. London: Routledge.

Newbery, D. M. G. and Stiglitz, J. E. 1981. The Theory of Commodity Price Stabilization. Oxford: Clarendon Press.

O’Donnell, R. M. 1989. Keynes: Philosophy, Economics and Politics. London: Macmillan.

Pasinetti, L.L. 2007. Keynes and the Cambridge Keynesians. Cambridge: Cambridge University Press.

Ricardo, D. 1951a. On the Principles of Political Economy and Taxation, P. Sraffa (ed.). Cambridge: Cambridge University Press.

Ricardo, D. 1951b. Pamphlets and Papers: 1815-1823, P. Sraffa (ed.). Cambridge: Cambridge University Press.

Shleifer, A. and Vishny, R. W. 1997. "The Limits of Arbitrage.” Journal of Finance 52 (1): 35-55.

Snyder, C. 1934. "Commodity Prices Versus the General Price Level." American Economic Review 24 (3): 385-400

Sraffa, P. 1960. Production of Commodities by Means of Commodities. Cambridge: Cambridge University Press.

Steil, B. 2013. The Battle of Bretton Woods. Princeton, NJ: Princeton University Press.

Targetti, F. 1992. Nicholas Kaldor. Oxford: Clarendon Press.

Targetti, F. \& Thirlwall, A.P. (eds.) 1989. The Essential Kaldor. London: Duckworth.

Thirlwall, A.P. 1987. Nicholas Kaldor. Brighton: Wheatsheaf Books.

Tyszynski, H. 1950. “A Note on International Commodity Agreements.” Economica 17 (68): 438-47.

Tinbergen, J. 1952. On the Theory of Economic Policy. Amsterdam: NorthHolland Publishing Company.

United Nations Conference on Trade and Development. 2019. State of Commodity Dependence 2018. Geneva. 
Ussher, L. 2009. "Global Imbalances and the Key Currency Regime: The Case for a Commodity Reserve Currency." Review of Political Economy 21 (3): $403-21$.

Ussher, L. 2016. "International monetary policy with commodity buffer stocks." European Journal of Economics and Economic Policies: Intervention 13 (1): $10-25$.

Ussher, L., Haas, A, Töpfer, K \& Jaeger, C.C. 2018. "Keynes and the International Monetary System: Time for a Tabular Standard?" European Journal of the History of Economic Thought 25 (1): 1-35.

Williams, J. C. and Wright, B. D. 1991. Storage and commodity markets. Cambridge: Cambridge University Press.

Woods, J. E. 2013. “On Keynes as an Investor.” Cambridge Journal of Economics 37 (2): 423-42.

Zhou, Xiaochuan. 2009. "Reform the international monetary system." Bank for International Settlements. 